\title{
Teacher's acceptance toward cloud-based learning technology in Covid-19 pandemic era
}

\author{
Ika Qutsiati Utami ${ }^{1}$ (D) Indah Fahmiyah ${ }^{1} \cdot$ Ratih Ardiati Ningrum $^{1}$ • \\ M. Noor Fakhruzzaman ${ }^{1}$ Angga Iryanto Pratama ${ }^{1}$. \\ Yohanes Manasye Triangga ${ }^{1}$
}

Received: 6 August 2021 / Revised: 24 November 2021 / Accepted: 29 November 2021 / Published online: 6 January 2022

(C) Beijing Normal University 2021

\begin{abstract}
Cloud-based learning technologies play a central role in ensuring that learning and teaching practice can be conducted properly in the Covid-19 pandemic era. Although such technologies are advanced in mediating educational practice, the teacher's acceptance toward the technology is usually far less to be understandable. This research aimed to investigate teachers' acceptance toward cloud-based learning technology, in particular, for Microsoft 365 that currently being used massively in facilitating the educational process in Indonesia. In terms of theoretical framework, Technology Acceptance Model was employed with the inclusion of two original constructs, i.e., perceived usefulness (PU), perceived ease of use (PEU), and two extensive variables, i.e., perceived risk (PR) and social influence (SI) that will predict teacher's intention to use the cloud-based learning technology during the Covid-19 pandemic. We collected data from teachers as research participants $(N=75)$ using the online survey method and employed Structured Equation Modeling (SEM) using SmartPLS for quantitative data analysis. The result revealed significant relationship among factors affecting the use of the technology, except for PU (path coefficient $=0.120, p$ value $=0.415$ ) and PEU (path coefficient $=0.224, p$ value $=0.147$ ). Regarding this interesting result, we add final reflections and recommendations for future lines of works.
\end{abstract}

Keywords Covid-19 $\cdot$ Technology acceptance $\cdot$ Cloud service $\cdot$ Learning technology $\cdot$ Educational policies

Ika Qutsiati Utami

ika.qutsiati.utami@gmail.com

1 Engineering Department, Data Science Technology Study Program, Faculty of Advanced Technology and Multidiscipline, Universitas Airlangga, Surabaya, Indonesia 


\section{Introduction}

A Covid-19 pandemic that occurred in Indonesia and across the globe has caused an educational transformation in terms of learning and instruction. During the pandemic, most educational systems from elementary to tertiary level switched from face-to-face teaching-learning practice into remote instruction to minimize spreading the virus (Azubuike et al., 2021; Darici et al., 2021; Roy \& Cecchini, 2020). This challenging condition raised concern among teachers and educators to adjust their teaching strategies, teaching methods, and assessment procedures. When implementing instructional delivery in a remote situation, it is required for educational institutions to consider a new educational environment using digitalsupporting technology and online infrastructure. In harmony with this situation, cloud-based learning technology can be the best possible learning tool in transforming traditional education into online-based instruction.

The development of cloud technologies is deemed to be the most powerful supplement to support the flexibility and effectiveness of the learning procedure due to the advancement of high-speed internet connection (Wang et al., 2019). One example of cloud-based learning technology that is massively being used to facilitate online instruction in Indonesia during the pandemic situation is Microsoft 365. This software package enabled students and teachers to interact virtually and share educational content via internet connection. Microsoft 365 also provided a prominent video conference platform called Ms. Teams to facilitate the educational process during pandemics (Poston et al., 2020). However, many schools and higher educational institutions particularly for teachers and instructors remained in this new learning situation with little planning and prior experience. Besides the importance of cloud-based learning technologies, teachers' resistance toward it still exists in the educational practice (Nikian et al., 2013). On the other hand, little information about the feasibility and teachers' acceptance of learning technologies is available. When implementing teaching and learning in a pandemic situation, it is important to monitor that all teachers accept new educational environments and learning technologies equally well because they play an important part in delivering instructional practices (Revelle, 2019). Another challenge shared by the teachers is related to teachers' digital natives that most of the teachers are not familiar with digital learning tools and the online environment. Furthermore, they are worried to spend too much time learning about the technology adopted by the schools that will affect their adoption rate.

This study aimed to investigate teachers' acceptance toward cloud-based learning technology, i.e., Microsoft 365 that the elementary to tertiary level schools have implemented during the pandemic situation in Indonesia. We focused on assessing three main features of the Microsoft 365 package such as Ms. Teams, Ms. Sway, and Ms. One Note Class Notebook that are being used mostly in teaching-learning practice. The original constructs from TAM, i.e., PU and PEU were used in this study. However, the original model of TAM did not account for social influence in relation to technology adoption. Whereas, effective utilization of new digital technologies and information systems is dependent upon social influence. 
It also can relate to individual acceptance and usage behavior. Additionally, educational activity is categorized as a social activity, so we extended the model to measure if the social influence variable can predict teachers' intention to use the learning technology. We also added perceived risk on the external variable of TAM because of the importance of risk as a key predictor of human behavior. Through this research, the educational institutions will further realize how cloud computing can be used effectively in the educational sector so that they can improve the status of cloud-based teaching and learning. Moreover, the TAM analysis that is presented in this study will convey valuable information for future research that will explore teachers' perceptions and acceptance toward cloudbased learning technologies from various perspectives.

\section{Literature review}

\section{Teacher's technology acceptance}

Learning technologies have received serious attention for the last two decades. Technology has enabled learning and teaching to be conducted in an active and autonomous situation. On the other hand, teachers play an important part in delivering successful instructional practices (Revelle, 2019). The teacher's role comprises curriculum enactor, learning mediator, examiner, and educator (Davis et al., 2017; Remillard, 2005). Research also reported that many teachers contributed to the improvement of student learning outcomes (Tamim \& Grant, 2013). Similar findings reported teachers' influence in improving students' ability to work together (Parsons et al., 2010). Although previous studies provided evidence that teachers have an important contribution in learning and instructional practice, they still need technical support and enough online infrastructures in daily instructional activities to support teaching. When working with the learning technologies and learning tools, teachers' technology acceptance has long been identified as a strong determinant of successful online learning practices (Althuizen, 2018; Godin, et al., 2016; Huang, 2017; Khlaisang et al., 2019; Okumus et al., 2018). In the original concept, studies of technology acceptance measure behavioral intention to use the technology (Maican et al., 2019; Šumak \& Šorgo, 2016; Uğur \& Turan, 2018). Teachers' technology acceptance comprises some predictors to measure their intention in utilizing the specific learning technology, for instance, PU and PEU as a significant determinant. Additionally, in the previous studies, other constructs such as PR and SI were considered as strong predictors of intention to use the technology (Kamal et al., 2020).

\section{Cloud-based learning technology}

The advancement of technology and information system in the context of educational studies led to the incremental change to the current learning technologies. Students, teachers, and all institutional members should prepare themselves for this rapid advancement and adapt themselves to educational transformation. Educational 
institutions required adjustment of technologies to improve the quality of learning and teaching methods to fulfill instructional policy standards (Sathaporn \& Panita, 2015). In the online education phenomenon impacted by Covid-19 pandemics, a lot of learning technologies emerged with advanced computing and technological support. Learning technologies with computing paradigm enabled distributed services and distributed users in cloud-based learning platforms (Xun, 2012). A cloud computing system built upon the model of a web browser or application can enable learning facilities for the interactive environment and online activities. It can also become a communication medium for students and teachers in the time of the Covid-19 pandemic.

Learning technologies supported by cloud computing allowed students and teachers to interact via internet connection without a compatibility issue of hardware and software, as well as the limitation of operating system (Carroll \& Merwe, 2011; Rimal et al., 2009). Students and teachers are facilitated with new learning models and perspectives. One of the prominent examples of cloud-based services supporting learning is Microsoft Office 365 offered by Microsoft. It provided powerful online services for education including communication tools, collaborative services, applications, and data storages capabilities (Office 365 Education, 2021). Many educational institutions from schools to universities take advantage of this technology to support remote learning and collaborative work. This study focused on specific features of Microsoft 365 that have been used by schools in Indonesia during the Covid-19 pandemic, i.e., Microsoft Teams for conference platform, Microsoft OneNote Class Notebook for class management, and Microsoft Sway for creating interactive learning content and presentation.

\section{Technology Acceptance Model (TAM)}

Technology acceptance refers to the individual choice to voluntarily accept and adopt technology (Kamal et al., 2020). To understand the important attributes of technology acceptance and effectiveness, many researchers developed models and conducted evaluation process multiple times (Carter \& Bélanger, 2005). One of the well-established frameworks in measuring users' acceptance toward specific technologies is Technology Acceptance Model or better known as the TAM method that was originally constructed by Davis (1989). TAM as the theoretical framework is widely used by researchers in various studies to predict the adoption and the future use of technology or product (Chau \& Hu, 2002; Hwang et al., 2018, 2019; Yi et al., 2006). It consists of two core constructs as significant determinants of technology acceptance, PU and PEU. PU is generally defined as the user's belief in the value of a working system that will assist them in enhancing their work performance. Whereas, PEU measured the degree of an individual's belief that using particular technology or system will be free of a vigorous effort (David, 1989; Elkaseh et al., 2016). However, using TAM for a specific context, PEU and PU may not sufficiently determine the individual's intention to use the technologies. Based on that, the utilization of additional variables should be adopted to bring better insight into users' perceptions. Within the context of this research, we added other variables including 
SI and PR as the two external constructs to predict teachers' intention to use cloudbased learning technologies.

\section{Social influence (SI) and perceived risk (PR)}

SI is the process by which an individual's beliefs are affected by the action or presence of others (Venkatesh et al., 2003). People of developing countries are dependent on each other in terms of social context so that it is critical to investigate the degree of SI as predictive factors of teachers' technology adoption. Moreover, a significant relationship was confirmed between SI and the intention to use the learning technologies (Roca \& Gagné, 2008). In the context of this study, we defined SI as encouragement and preventive action made by others to use cloud-based learning technologies. A pressure and encouragement from peers, supervisors, faculty, or principal can affect teachers' perception of technology use. Furthermore, PR is defined as the individual's perception of a specific decision to undertake an activity or action (Nicolaou \& McKnight, 2006). The importance of risk as a key predictor of human behavioral intention to use the particular system can't be denied. In the domain of educational studies and related research, uncertainty and risk are always linked with the adoption of information and communication technologies (ICT's). In general, risk has been categorized into six criteria consisting of financial risk, social risk, performance risk, psychological risk, safety risk, and time/opportunities risk (Cunningham, 1967). In our study, perceived risk by teachers was linked with their perception about safety and performance risk in conducting teaching activities during Covid-19 pandemics.

\section{Hypotheses development and research model}

Based on the original version of the TAM proposed by Davis (1989), this study used the two core constructs of TAM, i.e., PU and PEU to predict intention to use the cloud-based learning technology. We also included other variables such as SI and PR to obtain a better result on teachers' perceptions. All constructs are hypothesized in this study to investigate their relationship with the teacher's intention to use Microsoft 365 which refers to the individual's readiness to adopt, accept, or use it in educational practice. The research model is represented by Fig. 1 and the hypotheses are stated as follow:

Fig. 1 Research model

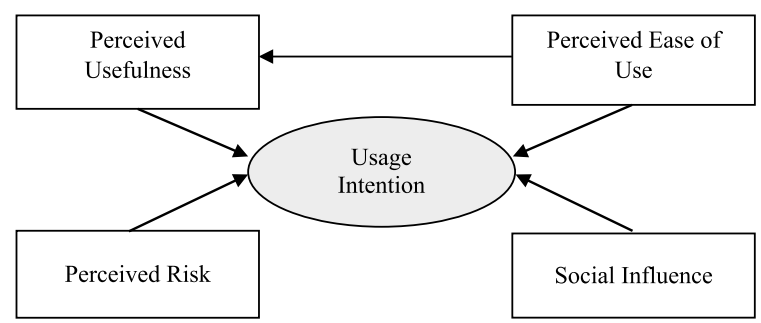


H1 Perceived Usefulness (PU) positively will influence intention to use the learning technology

H2 Perceived Ease of Use (PEU) positively will influence intention to use the learning technology

H3 Perceived Ease of Use (PEU) positively will influence Perceived Usefulness (PU)

H4 Social Influence (SI) positively will influence intention to use the learning technology

H5 Perceived Risk (PR) positively will influence intention to use the learning technology

\section{Methodology}

\section{Data collection}

The sample used in this study included teachers of schools in Surabaya City Indonesia. Due to school closures by the Indonesian government in May 2020, we distributed the questionnaire online and gathered a total of 75 responses for analysis using Google Form, survey distribution and administration software developed by Google Inc. Data collection lasted approximately two months. Respondent's answers were processed using Microsoft Excel for initial screening and moved to SmartPLS software for further statistical analysis. In this study, we used a quota sampling technique for the selection of the research sample involving individuals that represent a population. The respondent's profiles are shown in Table 1. The gender distribution of the respondents showed that female respondents (70.7\%) had a higher representation than male respondents $(29.3 \%)$. Respondents were identified as a younger group (6.7\%), age ranging 26 years until 35 years $(29 \%)$, moderate ranging 36 years until 45 years (29\%), and older people (33\%). Most of the respondents hold a bachelor's degree as a standard academic qualification for a teacher's career in Indonesia. A total of $76 \%$ of respondents showed an interesting result in Microsoft 365 usage in work although using this technology was made mandatory for teachers in Surabaya City.

\section{Data analysis}

After the data collection process, we performed statistical analysis to the data based on Structural Equation Modeling (SEM) to explain the possible relationships among constructs used in the study. We used a statistical approach to test the hypotheses between latent and observed variables in a research model (Fig. 1). In this state, we employed a measurement model and structural model using SmartPLS 3. SEM also 
Table 1 Demographic analysis

\begin{tabular}{|c|c|c|}
\hline Variable & Frequency & Percent $(\%)$ \\
\hline \multicolumn{3}{|l|}{ Gender } \\
\hline Male & 22 & 29.3 \\
\hline Female & 53 & 70.7 \\
\hline \multicolumn{3}{|l|}{ Age } \\
\hline Between 18 and 25 years & 5 & 6.7 \\
\hline Between 26 and 35 years & 29 & 38.7 \\
\hline Between 36 and 45 years & 16 & 21.3 \\
\hline 45 years or above & 25 & 33.3 \\
\hline \multicolumn{3}{|l|}{ Qualification } \\
\hline Associate degree & 3 & 4.0 \\
\hline Bachelors & 65 & 86.7 \\
\hline Masters & 7 & 9.3 \\
\hline Doctorate & 0 & 0 \\
\hline \multicolumn{3}{|l|}{ Microsoft 365 usage in work } \\
\hline Everyday & 0 & 0 \\
\hline $3-4$ days in a week & 7 & 9.3 \\
\hline $1-2$ days in a week & 11 & 14.7 \\
\hline Less than 4 days in a month & 57 & 76.0 \\
\hline
\end{tabular}

can generate techniques for comprehensive statistical approach, i.e., factor analysis, path analysis, discriminant analysis, and multiple regression. The questionnaire items for PU, PEU, and IU were adapted from well-validated scales of the previous studies (David, 1989; Venkatesh \& Davis, 2000). Questions on SI were adapted from two research studies (Kohnke et al., 2014; Venkatesh et al., 2012) and questions for PR are derived from TAM-related research (Javadi et al., 2012; Kim, 2012). The scale for measuring all constructs was based on a five-point Likert scale design and consisted of 18 items: five items from PEU, five items from PU, three items from PR, three items from SI, and two items from IU. The first stage of the analytical process is to evaluate the initial reliability of all constructs using SPSS statistics software. Each construct has a value of Cronbach's alpha above the threshold of 0.70 (Hair et al., 2019) indicating the acceptable level of reliability.

\section{Result}

\section{Measurement model assessment}

In this study, we conducted SEM analysis using two models, i.e., the measurement model and structural model. The measurement model focused on the investigation of the outer model to evaluate the reliability and the validity of each construct. Whereas, the structural model focused on the inner model to investigate the causal relationships among all the constructs. We performed a measurement model based on the model indicators by Hair et al. (2019) consisting of item loadings, internal 
consistency reliability, convergent validity, and discriminant validity. In terms of internal consistency reliability, Cronbach's alpha $(\alpha)$ and Composite Reliability (CR) were calculated to measure the statistical consistency across indicators.

Table 2 revealed the details of Partial Least Square Structural Equation Modeling (PLS-SEM) results including values of item loadings and internal consistency reliability. All constructs (i.e., PU, PEU, PR, SI, and IU) possessed item loadings that exceeded the recommended threshold of 0.70 (Muhaimin et al., 2020). On the other hand, the values of Cronbach's alpha $(\alpha)$ and Composite Reliability (CR) for all constructs surpassed 0.70 indicating an acceptable threshold for internal consistency (Hair et al., 2019). Furthermore, we used the Average Variance Extracted (AVE) parameter to check the convergent validity of the construct. Regarding the result demonstrated in Table 2, the AVE scores of all constructs were higher than the tolerated value of 0.50 (Fornell \& Larcker, 1981). In the measurement model, AVE higher than 0.50 means the items explain fewer errors than the variance in constructs.

In addition, based on the Fornell-Larcker criterion (1981), AVE also can be used to check discriminant validity by comparing the square root of each construct's AVE should be greater than correlation coefficients between two constructs. Discriminant validity is the extent to which a construct is different from other constructs (Hair et al., 2019). Table 3 demonstrated discriminant validity and all the correlation coefficients were less than the square root of AVE (bold style and diagonal). Furthermore, estimating cross-loadings also can be used to evaluate discriminant validity.

Table 2 Internal consistency reliability and item loadings

\begin{tabular}{|c|c|c|c|c|c|}
\hline Constructs & Items & Loading & $\begin{array}{l}\text { Composite } \\
\text { reliability }\end{array}$ & $\begin{array}{l}\text { Average vari- } \\
\text { ance extracted }\end{array}$ & Cronbach's alpha \\
\hline \multirow[t]{5}{*}{ Perceived usefulness (PU) } & PU1 & 0.732 & \multirow[t]{5}{*}{0.925} & \multirow[t]{5}{*}{0.712} & \multirow[t]{5}{*}{0.897} \\
\hline & PU2 & 0.885 & & & \\
\hline & PU3 & 0.814 & & & \\
\hline & PU4 & 0.927 & & & \\
\hline & PU5 & 0.848 & & & \\
\hline \multirow[t]{5}{*}{ Perceived ease of use (PEU) } & PEU1 & 0.861 & \multirow[t]{5}{*}{0.955} & \multirow[t]{5}{*}{0.809} & \multirow[t]{5}{*}{0.941} \\
\hline & PEU2 & 0.900 & & & \\
\hline & PEU3 & 0.908 & & & \\
\hline & PEU4 & 0.922 & & & \\
\hline & PEU5 & 0.906 & & & \\
\hline \multirow[t]{3}{*}{ Social influence (SI) } & SI1 & 0.778 & \multirow[t]{3}{*}{0.839} & \multirow[t]{3}{*}{0.635} & \multirow[t]{3}{*}{0.719} \\
\hline & SI2 & 0.854 & & & \\
\hline & SI3 & 0.754 & & & \\
\hline \multirow[t]{3}{*}{ Perceived risk (PR) } & PR1 & 0.799 & \multirow[t]{3}{*}{0.901} & \multirow[t]{3}{*}{0.752} & \multirow[t]{3}{*}{0.840} \\
\hline & PR2 & 0.906 & & & \\
\hline & PR3 & 0.894 & & & \\
\hline \multirow[t]{2}{*}{ Intention to use (IU) } & IU1 & 0.939 & \multirow[t]{2}{*}{0.946} & \multirow[t]{2}{*}{0.898} & \multirow[t]{2}{*}{0.887} \\
\hline & IU2 & 0.956 & & & \\
\hline
\end{tabular}


Table 3 Discriminant validity

\begin{tabular}{lrrrrr}
\hline Constructs & \multicolumn{1}{l}{ IU } & \multicolumn{1}{l}{ PEU } & \multicolumn{1}{l}{ PR } & PU & \multicolumn{1}{l}{ SI } \\
\hline IU & $\mathbf{0 . 9 4 7}$ & & & & \\
PEU & 0.541 & $\mathbf{0 . 9 0 0}$ & & & \\
PR & -0.246 & -0.262 & $\mathbf{0 . 8 6 7}$ & & \\
PU & 0.603 & 0.824 & -0.310 & $\mathbf{0 . 8 4 4}$ & \\
SI & 0.637 & 0.268 & 0.165 & 0.390 & $\mathbf{0 . 7 9 7}$ \\
\hline
\end{tabular}

All indicators' values (in bold style) for the outer loadings of each construct are presented in Table 4. The values in bold style were greater than the cross-loadings values of other constructs. In this situation, the emergence of discriminant validity can be identified by the examination of the cross-loading. Thus, we concluded that the measurement model used in this study is satisfactory.

\section{Collinearity assessment}

In this study, we presented the result of collinearity issues in the SEM model. When two predictors have a linear association, then collinearity emerges. With the availability of latent-modeling software like SmartPLS, all latent variables can be examined for collinearity with minimum effort. The examination of the Variance Inflation Factor (VIF) can be used to report collinearity issues. Low correlation among variables can be identified by a small VIF value. In an ideal condition, VIF values should

Table 4 Cross loading

\begin{tabular}{lrrrrl}
\hline Constructs & \multicolumn{1}{l}{ IU } & \multicolumn{1}{l}{ PEU } & \multicolumn{1}{l}{ PR } & \multicolumn{1}{l}{ PU } & \multicolumn{1}{l}{ SI } \\
\hline IU1 & $\mathbf{0 . 9 3 9}$ & 0.472 & -0.154 & 0.521 & 0.575 \\
IU2 & $\mathbf{0 . 9 5 6}$ & 0.547 & -0.301 & 0.615 & 0.629 \\
PEU1 & 0.472 & $\mathbf{0 . 8 6 1}$ & -0.233 & 0.701 & 0.192 \\
PEU2 & 0.432 & $\mathbf{0 . 9 0 0}$ & -0.213 & 0.786 & 0.233 \\
PEU3 & 0.495 & $\mathbf{0 . 9 0 8}$ & -0.230 & 0.669 & 0.238 \\
PEU4 & 0.498 & $\mathbf{0 . 9 2 2}$ & -0.239 & 0.777 & 0.281 \\
PEU5 & 0.533 & $\mathbf{0 . 9 0 6}$ & -0.265 & 0.766 & 0.258 \\
PR1 & -0.144 & -0.165 & $\mathbf{0 . 7 9 9}$ & -0.178 & 0.132 \\
PR2 & -0.222 & -0.215 & $\mathbf{0 . 9 0 6}$ & -0.245 & 0.142 \\
PR3 & -0.252 & -0.279 & $\mathbf{0 . 8 9 4}$ & -0.348 & 0.154 \\
PU1 & 0.484 & 0.548 & -0.143 & $\mathbf{0 . 7 3 2}$ & 0.388 \\
PU2 & 0.546 & 0.702 & -0.309 & $\mathbf{0 . 8 8 5}$ & 0.357 \\
PU3 & 0.455 & 0.716 & -0.219 & $\mathbf{0 . 8 1 4}$ & 0.254 \\
PU4 & 0.565 & 0.753 & -0.360 & $\mathbf{0 . 9 2 7}$ & 0.382 \\
PU5 & 0.492 & 0.742 & -0.251 & $\mathbf{0 . 8 4 8}$ & 0.273 \\
SI1 & 0.318 & -0.033 & 0.326 & 0.079 & $\mathbf{0 . 7 7 8}$ \\
SI12 & 0.579 & 0.190 & 0.024 & 0.290 & $\mathbf{0 . 8 5 4}$ \\
SI3 & 0.547 & 0.384 & 0.134 & 0.469 & $\mathbf{0 . 7 5 4}$ \\
\hline & & & & &
\end{tabular}


Table 5 VIF values

\begin{tabular}{llllll}
\hline & IU & PEU & PR & PU & SI \\
\hline IU & & & & & \\
PEU & 3.156 & & & 1.000 & \\
PR & 1.238 & & & & \\
PU & 3.725 & & & & \\
SI & 1.334 & & & & \\
\hline
\end{tabular}

Table 6 Hypotheses testing

\begin{tabular}{llcrrl}
\hline Hypothesis & Path & Path coefficients & $p$ value & $t$ value & Status \\
\hline $\mathrm{H} 1$ & $\mathrm{PU} \rightarrow \mathrm{IU}$ & 0.120 & 0.415 & 0.804 & Rejected \\
$\mathrm{H} 2$ & $\mathrm{PEU} \rightarrow \mathrm{IU}$ & 0.224 & 0.147 & 1.465 & Rejected \\
$\mathrm{H} 3$ & $\mathrm{PEU} \rightarrow \mathrm{PU}$ & 0.824 & $<0.001$ & 15.928 & Accepted \\
$\mathrm{H} 4$ & $\mathrm{SI} \rightarrow \mathrm{IU}$ & 0.571 & $<0.001$ & 5.856 & Accepted \\
$\mathrm{H} 5$ & $\mathrm{PR} \rightarrow \mathrm{IU}$ & -0.245 & 0.009 & 2.727 & Accepted \\
\hline
\end{tabular}

be under the value of 3. However, if the VIF value is lower than 10, it is still acceptable (Hair et al., 2019). Collinearity issues were not encountered in this study since the maximum VIF value is 3.725 which is lower than 10 (Muhaimin et al., 2020). The PEU, EU, PR, and SI have a role as a predictor of intention to use the cloudbased learning technology. Additionally, PEU can predict the values of PU. Table 5 presented all values of Variance Inflation Factor (VIF).

\section{Structural model assessment}

All hypotheses were accepted except $\mathrm{H} 1$ and H2. PU and PEU cannot significantly predict teachers' intention to use the cloud-based learning technology by applying a 5\% level of significance (see Table 6). Besides, the relationship within the TAM, between PEU and PU was addressed in H3. It posited that PEU had a direct effect on PU with a $p$ value $<0.001$. H4 investigated the relationship between SI and IU. The finding revealed that SI positively predicted IU $(p<0.001)$. Our results also confirmed the relationship between PR and IU in H5 $(p=0.009)$. Furthermore, the $t$-statistic is used in a $t$ test to support the result of hypothesis testing. The $t$ values in Table 6 are compared to $t_{0.025,74}=1.99$ derived from $t$ distribution with a significance level of 0.05 and 74 degrees of freedom. The $t$ values for $\mathrm{H} 3, \mathrm{H} 4$, and $\mathrm{H} 5$ are greater than 1.99, different from the others, i.e., H1 and H2. Therefore, the results indicated that PEU influences PU. SI and PR also influence the intention to use cloud-based learning technology. However, this study cannot conclude that PU and PEU influence intention to use the learning technology since the $t$ values for H1 and $\mathrm{H} 2$ are lower than 1.99. We presented the final SEM model of this study in Fig. 2. 


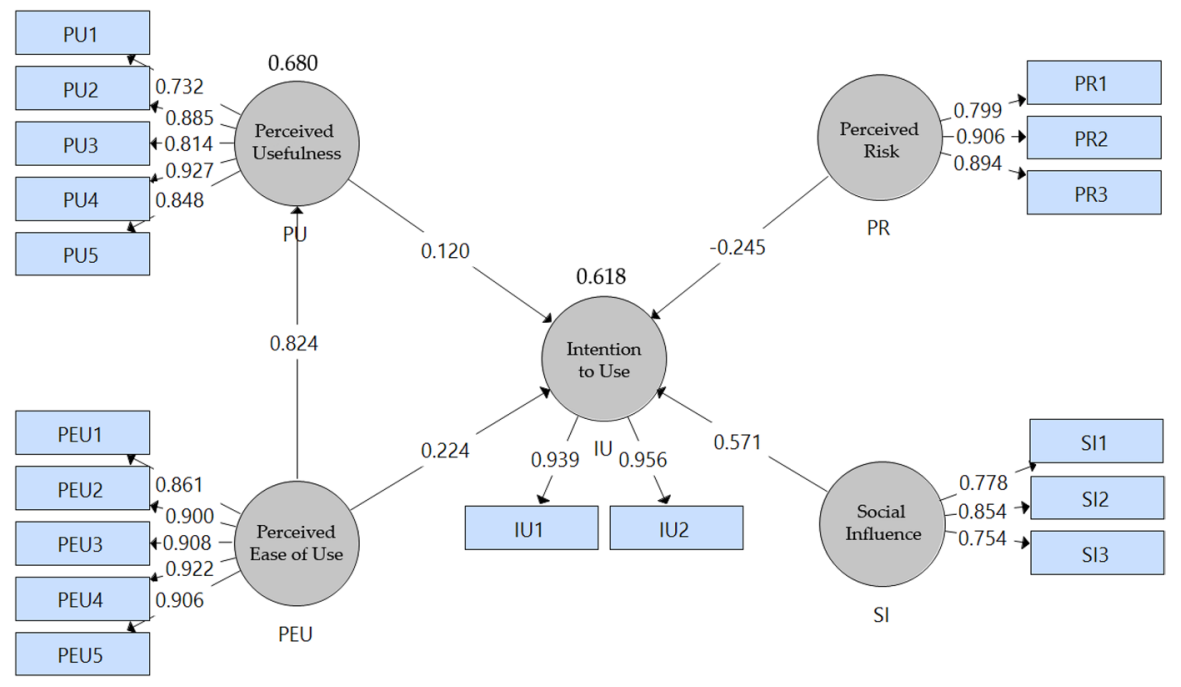

Fig. 2 Final model

\section{Discussion and conclusions}

An extended TAM with the inclusion of two external variables, i.e., PR and SI was used in this study to predict the adoption of cloud-based learning technology (i.e., Microsoft 365) during the Covid-19 pandemic perceived by primary school teachers. The reliability and validity of the model were guaranteed by the measurement model and content validity. From the results, it can be inferred that SI and PR affect teachers' acceptance of the learning technology. The adoption of learning technology by teachers in Indonesia was primarily influenced by others including peers and family members. The influence of social support is deemed necessary to adopt new learning technologies or learning systems. In addition, this study found PR significantly predicted intention to use the learning technology. This result added more contextual evidence that perceived risk in the educational context should be considered. Teachers perceived a low risk toward Covid-19 pandemics at the time of school resumption by conducting learning and teaching online. Cloud-based learning technology such as learning applications included in Microsoft 365 can help teachers to minimize the spreading of the virus.

Moreover, this study found an interesting result and draw the author's attention toward the relationship among TAM original constructs, i.e., PU, PEU, and IU. While most of the TAM-related studies provided a positive correlation, our study revealed different results toward the intention to use. PU and PEU did not directly affect the intention to use the cloud-based learning application. Teachers valued that online learning supported by Microsoft 365 applications is challenging since the technologies provide a lot of functional aspect for teaching practice that teachers are not familiar with before. Another possible reason is that the learning technology is usually not user-friendly on the teacher's side. They perceived Microsoft Teams and 
other supporting applications are hard to use for instructional activities during the Covid-19 pandemic. Another explanation is that the relationship between PU, PEU, and the intention to use the learning technology may depend on the teacher's motivational judgment. We did not research antecedent variables previously that may influence TAM results with regards to this study context such as coercion factors, motivational context, and usability issues.

The same results are also encountered in several research studies in which PEU did not significantly influence users' intention to use a specific technology (Barry \& Jan, 2018; Chow et al., 2012; Khalifa \& Shen, 2008; Nasri \& Charfeddine, 2012). The ease-of-use aspect of the system did not guarantee the direct likelihood of behavioral intention to use the system unless the users are aware of the system's usefulness. In some situations, users will not necessarily use the specific technology although they know that the technology is easy to use. Another finding explained that the different backgrounds of respondents in terms of technological savvy led to a different perspective on IU. Similar TAM-related research by Park et al., (2012) and Kim (2014) also showed an insignificant correlation between PU and IU. Based on the finding, PU did not influence IU directly because users adopt the technologies due to reasons related to mandatory and prestige aspects. They adopt the technology without knowing and understanding the benefit of the features provided by a specific application appropriately.

The results of this study should be taken into consideration by the government since the utilization of the Microsoft 365 application by teachers in a specific area in Indonesia was made mandatory for instructional activities during the pandemics. The authors suggested adding technical and organizational resources to support the use of cloud-based learning applications and technologies during the Covid-19 pandemic. Schools also should always promote and facilitate teachers with a comfortable learning environment and technologies for effective teaching and learning practice during pandemics. Some practical strategies can be implemented to escalate teachers' intention in relation to cloud-based learning technologies adoption such as selecting appropriate cloud-based learning applications and providing offline or online training for teachers regularly because fluency in accessing cloud services and using cloud applications is essential.

\section{Limitations and future works}

The study used an extended technology acceptance model (TAM) by adding two external constructs, i.e., social influence and perceived risk. TAM has been widely implemented to explore the adoption of learning technologies. However, a few studies have investigated the adoption of cloud-based learning technologies during the Covid-19 pandemic. This research can add an important contribution to the academic literature in understanding teachers' perceptions toward the adoption of learning technologies, especially in pandemic conditions. The results of the study can be a guide for government to make a better decision in policy making particularly in adopting learning technologies during Covid-19 pandemics. Findings from this research also lay the foundation for guiding future TAM-related research especially 
for investigation in the time of Covid-19 pandemics. Nevertheless, this study is not without limitations. First, the total number of respondents joined should be enhanced to gather more data and in-depth statistical results. Second, we did not research antecedent variables previously that may influence TAM results such as coercion factors and motivational context. In addition, TAM-related research should evaluate all factors affecting the use of cloud-based learning technologies and be implemented for various settings and contexts. Finally, we recommend researching similar topics but from a different perspective, for example, to understand the use of learning technologies using qualitative data analysis. Research data can be collected through the interview session or focus group/individual discussions.

Funding This research was a part of a community development project supported by the Faculty of Advanced Technology and Multidiscipline Universitas Airlangga.

\section{Declarations}

Conflict of interest All authors solemnly declared no conflicts of interest concerning this research and publication process.

\section{References}

Althuizen, N. (2018). Using structural technology acceptance models to segment intended users of a new technology: Propositions and an empirical illustration. Information Systems Journal, 28(5), 879904. https://doi.org/10.1111/isj.12172

Azubuike, O. B., Adegboye, O., \& Quadri, H. (2021). Who gets to learn in a pandemic? Exploring the digital divide in remote learning during the COVID-19 pandemic in Nigeria. International Journal of Educational Research Open, 2-2, 100022. https://doi.org/10.1016/j.ijedro.2020.100022

Barry, M., \& Jan, M. (2018). Factors influencing the use of m-commerce: An extended technology acceptance model perspective. International Journal of Economics, Management and Accounting, 26, 157-183.

Carroll, M., \& Merwe, A. (2011). Secure cloud computing: Benefits, risks and controls. In Information security for South Africa. Johannesburg, South Africa: IEEE. https://doi.org/10.1109/ISSA.2011. 6027519

Carter, L., \& Bélanger, F. (2005). The utilization of e-government services: Citizen trust, innovation and acceptance factors. Information System Journal, 15(1), 5-25. https://doi.org/10.1111/j.1365-2575. 2005.00183.X

Chau, P. Y., \& Hu, P.J.-H. (2002). Investigating healthcare professionals' decisions to accept telemedicine technology: An empirical test of competing theories. Information \& Management, 39(4), 297-311. https://doi.org/10.1016/S0378-7206(01)00098-2

Chow, M., Herold, D. K., Choo, T. M., \& Chan, K. (2012). Extending the technology acceptance model to explore the intention to use second life for enhancing healthcare education. Computers \& Education, 59(4), 1136-1144. https://doi.org/10.1016/j.compedu.2012.05.011

Cunningham, M. S. (1967). The major dimensions of perceived risk. Risk taking and information handling in consumer behavior.

Darici, D., Reissner, C., Brockhaus, J., \& Missler, M. (2021). Implementation of a fully digital histology course in the anatomical teaching curriculum during COVID-19 pandemic. Annals of Anatomy, 236, 151718. https://doi.org/10.1016/j.aanat.2021.151718

David, F. D. (1989). Perceived usefulness, perceived ease of use, and user acceptance of information technology. MIS Quarterly, 13(3), 319-340. https://doi.org/10.2307/249008 
Davis, E. A., Palincsar, A. S., Smith, P. S., Arias, M. A., \& Kademian, S. M. (2017). Educative curriculum materials: Uptake, impact, and implications for research and design. Educational Researcher, 46(6), 293-304. https://doi.org/10.3102/0013189X17727502

Davis, F. D. (1989). Perceived usefulness, perceived ease of use, and user acceptance of information technology. MIS Quarterly, 13(3), 319-340. https://doi.org/10.2307/249008

Elkaseh, A. M., Wong, K. W., \& Fung, C. C. (2016). Perceived ease of use and perceived usefulness of social media for e-learning in Libyan higher education: A structural equation modeling analysis. International Journal of Information and Education Technology, 6(3), 192. https://doi.org/10.7763/ IJIET.2016.V6.683

Fornell, C., \& Larcker, D. F. (1981). Structural equation models with unobservable variables and measurement error: Algebra and statistics. Journal of Marketing Research, 18(3), 382-388. https://doi. org/10.1177/002224378101800313

Godin, J., Leader, L., Gibson, N., Marshall, B., Poddar, A., \& Cardon, P. W. (2016). Virtual teamwork training: factors influencing the acceptance of collaboration technology. International Journal of Information and Communication Technology, 10(1), 89. https://doi.org/10.1504/IJICT.2017.081003

Hair, J. F., Risher, J. J., Sarstedt, M., \& Ringle, C. M. (2019). When to use and how to report the results of PLS-SEM. European Business Review, 31(1), 2-24. https://doi.org/10.1108/EBR-11-2018-0203

Huang, L. (2017). Acceptance of mobile learning in classroom instruction among college english teachers in China using an extended TAM. In The 2017 international conference of educational innovation through technology (EITT). IEEE, Japan.

Hwang, W. Y., Utami, I. Q., \& Chen, H. (2018). An evaluation study of learning behaviors and achievements with Ubiquitous Fraction (u-Fraction) for elementary school student. In IEEE 18th international conference on advanced learning technologies (ICALT). Mumbai, India: IEEE. https://doi. org/10.1109/ICALT.2018.00087

Hwang, Y. Y., Utami, I. Q., Purba, S. D., \& Chen, H. S. (2019). Effect of Ubiquitous Fraction App on mathematics learning achievements and learning behaviors of Taiwanese students in authentic contexts. IEEE Transactions on Learning Technologies. https://doi.org/10.1109/TLT.2019.2930045

Javadi, M. H., Dolatabadi, H. R., Nourbakhsh, M., Poursaeedi, A., \& Asadollahi, A. R. (2012). An analysis of factors affecting on online shopping behavior of consumers. International Journal of Marketing Studies. https://doi.org/10.5539/ijms.v4n5p81

Kamal, S. A., Shafiq, M., \& Kakria, P. (2020). Investigating acceptance of telemedicine services through an extended technology acceptance model (TAM). Technology in Society, 60, 101212. https://doi. org/10.1016/j.techsoc.2019.101212

Khalifa, M., \& Shen, K. N. (2008). Explaining the adoption of transactional B2C mobile commerce. Journal of Enterprise Information Management, 21(2), 110-124. https://doi.org/10.1108/17410 390810851372

Khlaisang, J., Teo, T., \& Huang, F. (2019). Acceptance of a flipped smart application for learning: A study among Thai university students. Interactive Learning Environments. https://doi.org/10.1080/ 10494820.2019 .1612447

Kim, J. B. (2012). An empirical study on consumer first purchase intention in online shopping: Integrating initial trust and TAM. Electronic Commerce Research, 12, 125-150. https://doi.org/10.1007/ s10660-012-9089-5

Kim, S. H. (2014). A study on adoption factors of Korean smartphone users: A focus on TAM (Technology Acceptance Model) and UTAUT (Unified Theory of Acceptance and Use of Technology). Advanced Science and Technology Letters, 57(1), 27-30.

Kohnke, A., Cole, M. L., \& Bush, R. (2014). Incorporating UTAUT predictors for understanding home care patients' and clinician's acceptance of healthcare telemedicine equipment. Journal of Technology Management \& Innovation. https://doi.org/10.4067/S0718-27242014000200003

Maican, C. L., Cazan, A. M., Lixandroiu, R. C., \& Dovleac, L. (2019). A study on academic staff personality and technology acceptance: The case of communication and collaboration applications. Computers \& Education, 128, 113-131. https://doi.org/10.1016/j.compedu.2018.09.010

Muhaimin, A., Habibi, A., Mukminin, A., \& Hadisaputra, P. (2020). Science teachers' integration of digital resources in education: A survey in rural areas of one Indonesian province. Heliyon. https://doi. org/10.1016/j.heliyon.2020.e04631

Nasri, W., \& Charfeddine, L. (2012). Factors affecting the adoption of internet banking in Tunisia: An integration theory of acceptance model and theory of planned behavior. The Journal of High Technology Management Research, 23(1), 1-14. https://doi.org/10.1016/j.hitech.2012.03.001 
Nicolaou, A. I., \& McKnight, D. H. (2006). Perceived information quality in data exchanges: Effects on risk, trust, and intention to use. Information Systems Research, 17(4), 327-444.

Nikian, S., Nor, F. M., \& Aziz, M. A. (2013). Malaysian teachers' perception of applying technology in the classroom. Procedia - Social and Behavioral Sciences, 103, 621-627. https://doi.org/10.1016/j. sbspro.2013.10.380

Office 365 Education. (2021, May 22). Microsoft: https:/www.microsoft.com/id-id/education/products/ office

Okumus, B., Ali, F., Bilgihan, A., \& Ozturk, A. B. (2018). Psychological factors influencing customers' acceptance of smartphone diet apps when ordering food at restaurants. International Journal of Hospitality Management. https://doi.org/10.1016/j.ijhm.2018.01.001

Park, S. Y., Nam, M. W., \& Cha, S. B. (2012). University students' behavioral intention to use mobile learning: Evaluating the technology acceptance model. British Journal of Educational Technology, 43(4), 592-605. https://doi.org/10.1111/j.1467-8535.2011.01229.x

Parsons, S. A., Metzger, S. R., Askew, J., \& Carswell, A. R. (2010). Teaching against the grain: One title I school's journey toward project-based literacy instruction. Literacy Research and Instruction, 50(1), 1-14. https://doi.org/10.1080/19388070903318413

Poston, J., Apostel, S., \& Richardson, K. (2020). Using Microsoft Teams to enhance engagement and learning with any class: It's fun and easy. In Pedagogicon conference proceedings. 6. Eastern Kentucky University. https://encompass.eku.edu/pedagogicon/2019/guidinggrading/6

Remillard, J. (2005). Examining key concepts in teachers' use of mathematics curricula. Review of Educational Research, 75(2), 211-246. https://doi.org/10.3102/00346543075002211

Revelle, K. Z. (2019). Teacher perceptions of a project-based approach to social studies and literacy instruction. Teaching and Teacher Education, 84, 95-105. https://doi.org/10.1016/j.tate.2019.04.016

Rimal, B. P., Choi, E., \& Lumb, I. (2009). A taxonomy and survey of cloud computing systems. In Fifth international joint conference on INC, IMS and IDC. Seoul, South Korea: IEEE. https://doi.org/10. 1109/NCM.2009.218

Roca, J. C., \& Gagné, M. (2008). Understanding e-learning continuance intention in the workplace: A self-determination theory perspective. Computers in Human Behavior, 24(4), 1585-1604. https:// doi.org/10.1016/j.chb.2007.06.001

Roy, S. F., \& Cecchini, M. J. (2020). Implementing a structured digital-based online pathology curriculum for trainees at the time of COVID-19. Clinical Pathotology, 73, 444. https://doi.org/10.1136/ jclinpath-2020-206682

Sathaporn, Y., \& Panita, W. (2015). Development of a challenge based learning model via cloud technology and social media for enhancing information management skills. Procedia - Social and Behavioral Sciences, 174, 2102-2107. https://doi.org/10.1016/j.sbspro.2015.02.008

Šumak, B., \& Šorgo, A. (2016). The acceptance and use of interactive whiteboards among teachers: Differences in UTAUT determinants between pre- and post-adopters. Computers in Human Behavior, 64, 602-620. https://doi.org/10.1016/j.chb.2016.07.037

Tamim, S. R., \& Grant, M. M. (2013). Definitions and uses: Case study of teachers implementing projectbased learning. Interdisciplinary Journal of Problem-Based Learning. https://doi.org/10.7771/15415015.1323

Uğur, N. G., \& Turan, H. A. (2018). E-learning adoption of academicians: A proposal for an extended model. Behaviour \& Information Technology, 37(4), 393-405. https://doi.org/10.1080/0144929X. 2018.1437219

Venkatesh, V., \& Davis, F. D. (2000). A theoretical extension of the technology acceptance model: Four longitudinal field studies. Management Science, 46(2), 169-332. https://doi.org/10.1287/mnsc.46.2. 186.11926

Venkatesh, V., Morris, M. G., Davis, G. B., \& Davis, F. D. (2003). User acceptance of information technology: Toward a unified view. MIS Quarterly, 27(3), 425-478. https://doi.org/10.2307/30036540

Venkatesh, V., Thong, J. Y., \& Xu, X. (2012). Consumer acceptance and use of information technology: Extending the unified theory of acceptance and use of technology. MIS Quarterly, 36(1), 157-178. https://doi.org/10.2307/41410412

Wang, L.-Y.-K., Lew, S.-L., Lau, S.-H., \& Leow, M.-C. (2019). Usability factors predicting continuance of intention to use cloud e-learning application. Heliyon, 5(6), e01788. https://doi.org/10.1016/j. heliyon.2019.e01788

Xun, X. (2012). From cloud computing to cloud manufacturing. Robotics and Computer-Integrated Manufacturing, 28(1), 75-86. https://doi.org/10.1016/j.rcim.2011.07.002 
Yi, M. Y., Jackson, J. D., Park, J. S., \& Probst, J. C. (2006). Understanding information technology acceptance by individual professionals: Toward an integrative view. Information \& Management, 43(3), 350-363. https://doi.org/10.1016/j.im.2005.08.006

Publisher's Note Springer Nature remains neutral with regard to jurisdictional claims in published maps and institutional affiliations.

Ika Qutsiati Utami received the M.S. degree from Graduate Institute of Network Learning Technology, National Central University, Taiwan, in 2018. She is currently working as a lecturer at Faculty of Advanced Technology and Multidiscipline, Universitas Airlangga, Indonesia. Her research interests are in the areas of human computer interaction, learning technology, and learning analytics.

Indah Fahmiyah is currently working as a lecturer at the Faculty of Advanced Technology and Multidiscipline, Universitas Airlangga, Indonesia. Her research interests include linear regression, logistic and probit regression, multivariate analysis, time series analysis, and data mining.

Ratih Ardiati Ningrum is a lecturer and researcher at the Faculty of Advanced Technology and Multidiscipline, Universitas Airlangga, Indonesia. She graduated with a statistics master's joint degree program from National Chiao Tung University, Taiwan, and Institut Teknologi Sepuluh Nopember, Surabaya. Currently, her research focuses on survival analysis and structural equation modeling.

M. Noor Fakhruzzaman holds an interdisciplinary Master's Degree in Human-Computer Interaction and Journalism \& Mass Communication from Iowa State University. His current research interests fall between Data Science and Mass Communication, mainly automated media monitoring using Natural Language Processing. He currently is a lecturer at the Faculty of Advanced Technology and Multidiscipline, Universitas Airlangga, Indonesia.

Angga Iryanto Pratama are bachelor's degree students at the Data Science Technology Study Program, Faculty of Advanced Technology and Multidiscipline, Universitas Airlangga, Indonesia.

Yohanes Manasye Triangga are bachelor's degree students at the Data Science Technology Study Program, Faculty of Advanced Technology and Multidiscipline, Universitas Airlangga, Indonesia. 